\title{
Grapevine Farming and its Contribution to Household income and Welfare among Smallholder Farmers in Dodoma Urban District, Tanzania
}

\author{
James Lwelamira, John Safari ${ }^{*}$, Patrick Wambura \\ Institute of Rural Development Planning (IRDP), Dodoma, Tanzania \\ Email address: \\ jsafari@irdp.ac.tz (J. Safari) \\ To cite this article: \\ James Lwelamira, John Safari, Patrick Wambura. Grapevine Farming and its Contribution to Household income and Welfare among \\ Smallholder Farmers in Dodoma Urban District, Tanzania. American Journal of Agriculture and Forestry. Vol. 3, No. 3, 2015 , pp. 73-79. \\ doi: 10.11648/j.ajaf.20150303.12
}

\begin{abstract}
High incidence of poverty in semi-arid region of central Tanzania is one of the major development challenges in the area. This has mainly been caused by failures of major crops due recurrent drought. Production of high value horticultural crops under irrigation such as grapes could be one of the strategies to reduce the severity of poverty levels and food shortages in the area. A cross-sectional study was carried out in Dodoma urban district to (i) assess the role of grapevine farming on household income and welfare of small scale farmers, (ii) examine the factors that affect grapevine farming, and (iii) identify strategies for improving grapevine farming. Household food security status and consumption expenditure were assessed and used as proxy indicators of the household welfare. The study involved a total of 252 respondents (126 grape farmers and 126 non-grape farmers). Data were collected through interviews using semi-structured questionnaire and analyzed using Statistical Package for Social Sciences (SPSS) program version 20. Results show that grape farming contributes to more than one third (35.6\%) of total household income and plays an important role in household welfare. Average household consumption expenditure for grape farmers was twofold higher than that of non-grape farmers $(173,833 \mathrm{vs.} 84,485 \mathrm{TZS} ; \mathrm{t}=13.3, p<0.001)$. Score on household food insecurity index for grape farmers was 8.51 being lower than 11.9 for non-grape farmers $(\mathrm{t}=-5.7, p<0.05)$. Nevertheless, there are a number of challenges in grape farming. These include low price of grapes, high costs of inputs, limited access to market, prevalence of pests and diseases, inadequate storage facilities and limited access to quality seedlings. This study gives insights into grape farming as a mitigation strategy of food shortage and the overall household welfare under the changing environmental and socio-economic circumstances.
\end{abstract}

Keywords: Food Security, High Value Crop, Semi-Arid Areas

\section{Introduction}

High incidence of poverty especially in the rural areas is a major development challenge in Tanzania. Dodoma region in central Tanzania is semi-arid and among the regions with wide spread poverty $[18,26]$ and high prevalence of food insecurity $[1,28]$. The region experiences recurrent food shortages due to failure of major food crops [24, 27, 41]. The single most important trigger for crop failure has been drought [17, 39]. Rainfall is generally low and erratic which results in withered plants and greatly reduced yields [34, 37]. This condition is likely to be a manifestation of climate change which is often characterized by increased seasonal variability and frequency of extreme events. The changing conditions associated with climate change, generate more desire to build resilience into agricultural systems [22]. Indeed, this needs to be seen in the context of farming systems in particular and agricultural growth and development in general. Although farming systems located in hot and dry areas are expected to be most severely affected by these changes, there may be considerable differences in adaptive capacity between cropping systems.

In this regard, choice of cropping system as an adaptation and mitigation measure is critical in helping farmers achieve their food, income and livelihood security objectives. A rational method to enhance productivity may be achieved through increased crop diversification and adoption of drought tolerant crops. Cultivation of such crops can lead to increased intensity, food security, commercialization and employment $[3,40,7,43]$. It is argued that there has been no example of mass reduction of poverty in modern history that 
did not start with sharp rises in employment and self-employment income due to increased productivity among small family farms [23]

Evidence suggests that promoting high value and drought tolerant crops is a viable coping strategy of furthering poverty reduction and economic growth [5, 6, 15, 22, 38]. Grapevine (Vitisvinifera) is among such crops grown in Dodoma Urban district. Records show that during the past six years, the amount of grapes produced in the district increased by $73.8 \%$ i.e. 3930 tons in 2008 to 6831 tons in 2014 [8]. During this period, the number of grape growers rose from 768 to 1012 (31.8\% increase) indicating that grapevine is a crop of growing significance in the rural livelihoods in Dodoma areas. Nevertheless, grape farming in Tanzania is a subject of very limited information. To our knowledge, this is the first empirical study that examines in greater detail the role of grape farming in rural livelihoods in Tanzania. Food security (food availability, access and adequacy) and household consumption expenditure are known to be key indicators of household welfare $[19,31,32]$. In this study, we identify the links between grape farming, household income, food security and consumption expenditure. Analysis is required to improve understanding of potentials, challenges and strategies needed to improve grape sub-sector especially as the scale of production is growing. The objectives of the study were (i) to assess the role of grape farming on household income and welfare of small scale farmers (ii) to examine the factors that affect grape farming and (iii) to identify strategies for improving grapevine farming

\section{Methodology}

\subsection{Study Area}

This study was carried out in six villages (Mbabala A, Mbabala B, Mpunguzi, Matumbulu, Veyula, and Mchemwa) which were randomly selected from three wards (Mbabala, Mpunguzi and Makutupora). These wards are among the five wards in Dodoma Urban district with high proportion (3\%) of grape farmers [8]. This district has a total of 41 wards, 18 villages and 170 mitaa $^{l}$. The district has 410,956 inhabitants of whom 211,469 (51.5\%) are females and 199,487 (48.5\%) are males with the average household size of 4.4 [42]. The district lies between latitude $-6^{\circ} 9^{\prime} 35.028^{\prime \prime} \mathrm{N}$ and longitude $35^{\circ}$ $47^{\prime} 52.8^{\prime \prime}$ E with a size of $2,969 \mathrm{~km}^{2}$ (276,900 ha). A total of 196,000 ha are suitable for agriculture but only 107,007 ha are under cultivation [8]. In 2013/2014, an estimated 1242 ha $(0.1 \%$ of the total area suitable for cultivation) were under grape cultivation [8]. The study area is semi-arid characterized by a long dry season starting late April to early December, and a short single wet season starting December to mid April. The average rainfall is $500 \mathrm{~mm}$ annually, and about $85 \%$ of this falls in the four months between December and March. The study area cultivates a number of grape varieties including

1 The mtaa (plural mitaa) is the lowest unit of government in urban areas in Tanzania. Each urban ward is divided into mitaa or neighbourhoods consisting of a number of households, which the urban council may determine.
Makutupora red, Cheninblanc, Regina, Syrah, Ugniblanc, Black rose, Alphoncelavalle, Tajitrozavij, Beauty seedless, Kismiscreveni and Halelibelyji. There are two harvesting seasons - one in the rainy season (March, April and May) and another in the dry season (August, September and October). High grape production occurs during the dry season.

\subsection{Study Design}

A cross-sectional design was applied to enroll a random sample of 126 grape farmers (adopters) and 126 non-grape farmers (non-adopters) from six villages in September, 2013. A sample size for grape farmers (n) was estimated from $\frac{\left(Z_{\alpha / 2}\right)^{2} p q}{\lambda^{2}}$ [10]. Where, $Z_{\alpha / 2}=1.96, p=1-\mathrm{q}=0.5$, and $\lambda=$ maximum error $=10 \%$. Further, 95\% confidence interval and non-response rate of $10 \%$ were assumed. An equal number of non-grape farmers were included in the study for comparative analysis with respect to household income and welfare attributes. The study, therefore, involved a total of 252 respondents.

\subsection{Data Collection}

Respondents involved in this study were interviewed using a semi-structured questionnaire. The main aspects covered in the questionnaire were: Socio-demographic characteristics, farm size under grape, grape yield and household income. Others were household consumption expenditure, household food security status and constraints to grape production. Household consumption expenditure and household food security were used as proxy indicators of household welfare. Household consumption expenditure was derived from consumption expenditure on non- durable goods per adult equivalent per year as described in previous studies [4, 21, 2, 20]. Non-durable goods consisted of both food and non-food items. Food items consisted of dairy, grain, fruits/vegetables, eggs, meat/poultry/fish, legumes/nuts, oil/fats and beverages (coffee/tea/soft drinks). Non-food items included water bills and house rent, clothing (clothes, shoes and make-up), energy/fuel (firewood, charcoal, kerosene and electricity) and social activities (contribution to churches, mosques, local organizations, education and medical services). High total consumption expenditure on the above items indicated high level of the household welfare.

On the other hand, household food security status was assessed based on respondent's experience on household food status in the past 12 months prior to the survey. Respondents were therefore asked to rate the following items: worry about food, unable to eat preferred foods, go to bed hungry, go the whole day and night without food, eat food that really do not want to eat, eat small meal, eat fewer meals a day, no food of any kind in the household [4,30]. Rating of each of these items was based on a 3-point Likert scale: $0=$ no, $1=$ rarely, 2 $=$ sometimes and $3=$ often. Scores were then summed to obtain food insecurity index. High score on the index is an indication of high level of household food insecurity. In addition to household survey, data were collected from the 
department of agriculture at the district and key informants.

\subsection{Data Analysis}

Quantitative data were analyzed using SPSS version 20. The analysis involved descriptive statistics to determine distributions of means, standard deviations, frequencies and percentages. Inferential statistical analysis was performed to compare grape farmers with non-grape farmers with respect to socio-demographic characteristics, income levels and household welfare attributes. In addition, t-test was used to analyze continuous data while Chi-square test was used to analyze categorical data.

\section{Results and Discussion}

\subsection{Characteristics of Respondents}

Socio-demographic characteristics of respondents are presented in Table 1. Distribution of respondents varied among age groups and sex $(p<0.05)$ between grape farmers and non- grape farmers. The majority of grape farmers $(80.2 \%)$ were aged 35-64 and that grape farming was a predominantly male activity (75.4\%, male; $24.6 \%$ female). Married individuals constituted the highest group engaged in farming activities compared to other categories. Large family size (6 members and above) was a characteristic observed from $31 \%$ of grape farmers compared to $24 \%$ of non-grape farmers $(p<0.05)$. Evidence from previous studies show large household size is associated with increased chances of adoption of new interventions $[11,16]$. This scenario could be attributed to increased labour force in large families. In this study, adoption of grape farming was independent of the education level $(p>0.05)$ which is probably due to the fact that majority of the respondents had similar education background. In other studies, however, increased education has been found to enhance adoption of agricultural technology [29, 33].

Table 1. Social demographic characteristics of the respondents.

\begin{tabular}{|c|c|c|c|c|}
\hline Variable & $\begin{array}{l}\text { Grape farmers } \\
(\mathrm{n}=126)\end{array}$ & $\begin{array}{l}\text { Non-grape farmers } \\
(n=126)\end{array}$ & $\begin{array}{l}\text { All } \\
(n=252)\end{array}$ & $\chi^{2}$-value \\
\hline \multicolumn{5}{|l|}{ Age } \\
\hline$<35$ & $18(14.3)$ & $36(28.6)$ & $54(21.4)$ & $8.45^{*}$ \\
\hline $35-64$ & $101(80.2)$ & $81(64.3)$ & $182(72.2)$ & \\
\hline $64+$ & $7(5.6)$ & $9(7.1)$ & $16(6.3)$ & \\
\hline \multicolumn{5}{|l|}{ Sex } \\
\hline Male & $95(75.4)$ & $85(67.5)$ & $180(71.4)$ & $2.16^{*}$ \\
\hline Female & $31(24.6)$ & $41(32.5)$ & $72(28.6)$ & \\
\hline \multicolumn{5}{|l|}{ Marital status } \\
\hline Married & $93(73.8)$ & $76(60.3)$ & $169(67.1)$ & $6.42 *$ \\
\hline Single & $17(13.5)$ & $32(25.4)$ & $49(19.4)$ & \\
\hline Others & $16(12.7)$ & $18(14.3)$ & $34(13.5)$ & \\
\hline \multicolumn{5}{|l|}{ Education level } \\
\hline None & $19(15.1)$ & $30(23.8)$ & $49(19.4)$ & $4.25 \mathrm{~ns}$ \\
\hline Primary & $89(70.6)$ & $85(67.5)$ & $174(69.0)$ & \\
\hline Secondary+ & $18(14.3)$ & $11(8.7)$ & $29(11.5)$ & \\
\hline \multicolumn{5}{|l|}{ Household size } \\
\hline Less than 6 & $87(69.0)$ & $98(77.8)$ & $185(73.4)$ & $2.54 *$ \\
\hline 6 and above & $39(31.0)$ & $28(22.2)$ & $67(26.6)$ & \\
\hline
\end{tabular}

Figures in parentheses are percentages; $\mathrm{ns}=$ not significant, * significant at $p<0.05$

\subsection{Farm Size and Grape Yield}

Table 2. Period in grape farming, farm size and grape yield $(n=126)$.

\begin{tabular}{lll}
\hline Variable & Frequency & Percent \\
\hline Number of years engaged in grape farming & & \\
$<5$ & 12 & 9.5 \\
$5-10$ & 76 & 60.3 \\
$>10$ & 38 & 30.2 \\
Farm size under grape production (acre) & & \\
$<2$ & 94 & 74.6 \\
$2-4$ & 22 & 17.5 \\
$>4$ & 10 & 7.9 \\
Total yield last year (ton) & & \\
$<1$ & 74 & 58.7 \\
$1-2$ & 45 & 35.7 \\
$>2$ & 7 & 5.6 \\
\hline
\end{tabular}

Results from Table 2 indicate that majority of respondents $(90.5 \%)$ were engaged in grape farming for at least 5 years. About seven in ten grape farmers $(74.6 \%)$ had less than two acres of land under grape production with average acreage of 2.1. More than half of grape growers $(58.7 \%)$ harvested below 1 ton of grapes per year. The average yield was 1.6 ton per acre per year which is somewhat lower than the district average of 2 tons per acre per year [8]. With improved technology and management practices, however, one acre can produce more than 8tons of grapes [25].

\subsection{Contribution of Grape Farming to Household Income}

To determine contribution of grape farming to household income, grape farmers were asked to indicate their annual income from grape farming and other sources. Income from farm produce was derived by multiplying the amount of a given crop harvested with its market price (TZS 800 for the case of grape; $1 \mathrm{USD} \approx \mathrm{TZS} 1800$ ). It was found that $73 \%$ of grape farmers earned $<1$ million TZS per year while $21.4 \%$ and 5.6\% earned 1-2 millions and $>2$ millions TZS per year, respectively. The average annual income per household from 
grape farming was $823,151 \mathrm{TZS}$ which is equivalent to $35.6 \%$ of the total income. This was followed by $620,079(26.8 \%)$ from other crops, 546,111 (23.6\%) from small scale business, $131468(5.7 \%)$ from livestock and livestock products and $191,904(8.3 \%)$ from other sources. Grape farming had the highest contribution to household income notwithstanding the observed low productivity and low price of grapes. This indicates high potential of reducing poverty levels through grape farming especially when grape productivity is improved.

\subsection{Contribution of Grape Farming to Household Welfare}

To determine the contribution of grape farming to the household welfare, household consumption expenditure on non- durable goods per adult equivalent and scores on household food insecurity index for grape farmers were compared with those for non-grape farmers. As shown in
Table 3, grape farmers had higher average household consumption expenditure per adult equivalent per year than non-grape farmers $(\mathrm{t}=13.30, p<0.001)$. On the other hand, low food insecurity index was recorded for grape farmers compared to non-grape farmers $(\mathrm{t}=-5.71, p<0.05)$ meaning that grape farmers were more food secure than non-grape farmers. These findings are supported by results in Table 4 which present respondents' judgment on the status of food security in their households. Only $11 \%$ of the grape farmers reported having had problems in meeting their food needs a year before the survey compared to $56.4 \%$ of non-grape farmers $(\chi 2=57.68, \quad p<0.001)$. Overall, $33.7 \%$ of all respondents were less food secure. Unlike grape farmers who generate income from grapes, non-grape farmers in the area depend entirely on selling food crops for income. This practice partly explains the observed higher level of food insecurity among non-grape farmers.

Table 3. Household consumption expenditure and score on household food insecurity index.

\begin{tabular}{|c|c|c|c|c|c|}
\hline \multirow{2}{*}{ Variable } & \multicolumn{2}{|c|}{ Grape farmers $(n=126)$} & \multicolumn{2}{|c|}{ Non- grape farmers $(n=126)$} & \multirow{2}{*}{ t-value } \\
\hline & Mean & SD & Mean & SD & \\
\hline Household consumption expenditure per adult equivalent per year (TZS) & 173,833 & 62,562 & 84,485 & 45,281 & $13.30 * * *$ \\
\hline Score on household food insecurity index & 8.51 & 4.17 & 11.98 & 5.41 & $-5.71 *$ \\
\hline
\end{tabular}

$\mathrm{SD}=$ Standard deviation; $*$ Significant at $p<0.05 ; * * *=$ Significant at $p<0.001$

Generally, hunger is commonly experienced for five months in the area, and the most critical months of food shortage are November, December, January, February and March. Analysis also showed that at least for a number of months, $72.9 \%$ of the respondents met their daily food needs through purchase, own production or by adopting various coping strategies. These included sale of liquid or productive assets, eating less often, borrowing money to buy food and doing casual labour. Because grape-growers were less subjected to the transient threat of food insecurity, most of them $(96.8 \%)$ were able to meet basic necessities throughout the year without selling productive or household assets as compared to $82.5 \%$ of non-grape farmers. It is intriguing to note that although grape productivity was low, grape farming improved the status of food security. These findings show the importance of high-value crops in household welfare as reported elsewhere [14, 36].

Table 4. Opinions of respondents on household food security status.

\begin{tabular}{llll}
\hline Variable & Grape farmers $(\mathbf{n}=\mathbf{1 2 6})$ & Non-grape farmers $(\mathbf{n}=\mathbf{1 2 6})$ & All(n=252) \\
\hline Food secure & $112(88.9)$ & $55(43.6)$ & $167(66.3)$ \\
Less food secure & $14(11.1)$ & $71(56.4)$ & $85(33.7)$ \\
\hline
\end{tabular}

Figures in parentheses are percentages, $* * *=$ Significant at $p<0.001$

\subsection{Constraints to Grape Farming}

Table 5 shows constraints of grape farming as experienced by farmers. These constraints are ranked and total weighted scores for each constraint is presented. Low price relative to input cost was the most important constraint. This is linked to limited access of grape market. The market is mainly domestic and grapes are sold as fresh fruits as there are no value-adding activities. However, there are few grape processing industries in Dodoma and their capacity is rather low. The market linkages for grapes are therefore weak and this is likely to undermine the overall growth of grape-subsector in the area.

During discussion with the key informants, it was revealed that except for a few cases in Mpunguzi, Mbabala A and Mbabala B where there are farmer organizations, most of them work independently. However, farmer organization is a critical factor in making markets work for the poor particularly in high value products [13]. Where farmers operate on independently, access to farm inputs/or market outputs is invariably more limiting and products are usually low paid $[35,36]$. Beyond prices, farmer groups function as important catalysts for adoption of innovation through promoting efficient information flows [9]. Thus, creating or strengthening farmer organizations needs to be considered as an important strategy for growth of grape- subsector.

Pests and diseases present another constraint. Important pests are grasshoppers, caterpillar, beetles and sucking insects while major diseases are powdery mildew and downry mildew. These diseases have significant effects on growth, yield and quality of grapes particularly sugar levels, juice colour and acidity [12]. Although data for grape losses due pests and diseases are not available, discussion with farmers clearly indicated that pests and diseases cause considerable damage to grapevine. 
Water shortage is among the dominant environmental constraint for grape production in this area. Farmers showed concern over increased price of water for irrigation which resulted in limited water use. Thus, grapevine often faced some degree of drought stress especially in the dry season. To cope with this limitation, some farmers particularly in Mpunguzi, Mbabala A and Mbabala B villages have developed irrigation system from ground water sources. Significant increase in grape production was reported due to this scheme. Nevertheless, the capital cost for developing a ground water supply is high. This is even more challenging as none of the farmers we interviewed had access to any credit scheme. As with any other agricultural activity, institutions in the commercial financial sector do not reach small scale farmers because of perceived risks. The farmers are, therefore, deprived of important tool for development. Grape farming is also constrained by the lack of appropriate storage facilities such that significant losses often occurred before the produce reached consumers.

Table 5. Constraints to grape farming.

\begin{tabular}{|c|c|c|c|c|c|c|}
\hline \multirow{2}{*}{ Constraint $^{\mathrm{a}}$} & \multicolumn{4}{|l|}{ Rank } & \multirow{2}{*}{ Total frequency } & \multirow{2}{*}{ Total weighted score ${ }^{a}$} \\
\hline & 1st & 2nd & 3rd & 4th & & \\
\hline Low price of grape & $70(280)$ & $34(102)$ & $10(20)$ & $3(3)$ & 117 & 405 \\
\hline High costs of inputs ${ }^{\mathrm{b}}$ & $20(80)$ & $40(120)$ & $10(20)$ & $7(7)$ & 77 & 227 \\
\hline Limited access to market & $30(120)$ & $10(30)$ & $6(12)$ & $7(7)$ & 53 & 169 \\
\hline Pests and diseases & $15(60)$ & $4(12)$ & $2(4)$ & $5(5)$ & 26 & 81 \\
\hline Water shortage & $12(48)$ & $5(15)$ & $1(2)$ & $3(3)$ & 21 & 68 \\
\hline Lack of storage facilities & $5(20)$ & $6(18)$ & $10(20)$ & $1(1)$ & 22 & 59 \\
\hline Limited access to quality seedlings & $2(8)$ & $4(12)$ & $6(12)$ & $3(3)$ & 15 & 35 \\
\hline
\end{tabular}

Figures outside parentheses are frequencies while those in parentheses are weighted scores. Weighted scores were obtained by multiplying frequencies by a weight of a respective rank with the $1^{\text {st }}, 2^{\text {nd }}, 3^{\text {rd }}$ and $4^{\text {th }}$ ranks taking a weight of $4,3,2$ and 1 , respectively. ${ }^{\text {a }}$ Total weighted score for each constraint was obtained

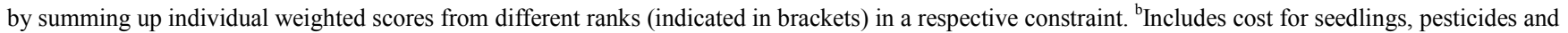
labour

\section{Conclusion and Recommendations}

This study has shown that grape farming is a significant driver for growth and a major source of income for the small scale farmers. Indeed, this activity plays an important role in household food security and the overall welfare of small scale farmers. However, limited access to market is a major constraint to full exploitation of grape production potential and jeopardizes efforts to improving productivity. In this regard, government intervention is needed to attract investment in grape processing industries which would broaden the range of products from grapes and enhance grape market. Improved linkage to existing markets along with provision of technical support is critical to the development of the grape sub-sector, and this would subsequently reduce rural poverty and food insecurity. As part of the endeavour to address these constraints, efforts are also needed to establish groups of producers and processors or strengthen the existing ones as a strategy to facilitate access to technical support, farm inputs, output market and financial services.

\section{References}

[1] Arndt, C., Farmer, W., Strzepek, K and Thurlow, J. 2012. Climate change, agriculture and food security in Tanzania. Review of Development Economics, 16(3), 378-393

[2] Asfaw, S., Shiferaw, B., Simtowe, F and Lipper, L. 2012. Impact of modern agriculture technologies on small holder farmer's welfare. Evidence from Tanzania and Ethiopia. Food policy, 37, 283-295.
[3] Brussaard, L., Caron, P., Campbell, B., Lipper, L., Mainka, S., Rabbinge, R and Pulleman, M. 2010. Reconciling biodiversity conservation and food security: scientific challenges for a new agriculture. Current Opinion in Environmental Sustainability, $2(1), 34-42$.

[4] Coates, J., Swindale, A and Bilinsky, P. 2007. Household food insecurity access scale (HFIAS) for measurement of food access. Indicator Guide. Food and Nutrition technical assistance, USAID.

[5] Cooper, P., Dimes, J., Rao, K., Shapiro, B., Shiferaw, B and Twomlow, S. 2008. Coping better with current climatic variability in the rain-fed farming systems of sub-Saharan Africa: An essential first step in adapting to future climate change? Agriculture, Ecosystems and Environment, 126(1), 24-35.

[6] Devereux, S and Edwards, J. 2004. Climate change and food security. IDS Bulletin, 35(3), 22-30.

[7] Di Falco, S and Chavas, J.P. 2009. On crop biodiversity, risk exposure, and food security in the highlands of Ethiopia. American Journal of Agricultural Economics, 91(3), 599-611.

[8] Dodoma Urban District Report, 2014. Annual Report.

[9] Fischer, E and Qaim, M. 2012. Linking smallholders to markets: determinants and impacts of farmer collective action in Kenya. World Development, 40(6), 1255-1268.

[10] Fisher, A.A., Laing, J.E., Townsend and J.W. 1991. Handbook for family planning operations research and design. Operations research. Population council, USA

[11] Franzel, S. 1999. Socio-economic factors affecting the adoption potential of improved tree fallows in Africa. Agro forestry Systems 47,305- 321. 
[12] Gadoury, D. M., Seem, R. C., Pearson, R. C., Wilcox, W. F and Dunst, R. M. 2001. Effects of powdery mildew on vine growth, yield, and quality of concord grapes. Plant Disease, 85(2), 137-140.

[13] Hellin, J., Lundy, M and Meijer, M. 2009. Farmer organization, collective action and market access in Meso-America. Food Policy, 34(1), 16-22.

[14] Hossain, M and Jaim, W. M. H. 2011. Empowering Women to Become Farmer Entrepreneur. In Paper presented at the IFAD Conference on New Directions for Smallholder Agriculture, Vol. 24, p. 25.

[15] IFAD.2008. International Fund for Agricultural Development. The role of high value crops in rural poverty reduction in the near east and North Africa.

[16] Junge, B., Deji, O., Abaidoo, R., Chikoye, D and Stahr, K. 2009 Farmers' Adoption of Soil Conservation Technologies: A Case Study from Osun State, Nigeria. The Journal of Agricultural education and extension. 15 (3), 257- 274.

[17] Kahimba, F.C., Mutabazi, K.D., Tumbo, S.D., Masuki, K.F and Mbungu, W.B. 2014. Scaling - up of conservation agriculture in Tanzania: A case of Arusha and Dodoma Regions. Natural Resources, 2014

[18] Kisusu, R. W.,Mdoe, N. S. Y.,Turuka, F. M and Mlambiti, M. E. 2000. Contribution of smallholder dairy production to food security, household income and poverty alleviation: the case of Mvumi dairy development project, Dodoma. In: Proceedings of the 18th Scientific Conference of the Tanzania Veterinary Association held at AICC, Arusha, Tanzania, 5-7 December 2000. Vol. 20 pp 89- 99

[19] Kulig, A., Kolfoort, H and Hoekstra, R. 2010. The case for the hybrid capital approach for the measurement of the welfare and sustainability. Ecological Indicators, 10(2), 118-128.

[20] Kuwornu, J.K.M and Eric S. O. 2012. Irrigation access and per capita consumption expenditure in farm households: Evidence from Ghana. Journal of Development and Agricultural Economics, 4 (3), 78-92.

[21] Langat, J.K., Mutai, B.K., Maina, M.C and Bett, H.K. 2011. Effect of Credit on Household Welfare: The Case of "Village Bank" Credit in Bomet County, Kenya. Asian Journal of Agricultural Sciences 3(3), 162-170.

[22] Lin, B. B. 2011. Resilience in agriculture through crop diversification: adaptive management for environmental change. BioScience, 61(3), 183-193.

[23] Lipton, M. 2005. 'The family farm in a globalizing world: The role of crop science in alleviating poverty'. Policy Brief 74. Washington, DC: IFPRI.

[24] Liwenga, E. 2003. Food Insecurity and Coping Strategies in Semiarid Areas. The Case of Mvumi in Central Tanzania. PhD thesis, Stockholm University, Stockholm, Sweden.

[25] Mgwasa, D. 2012. Tanzania Distillers Limited (TDL) contribution on Dodoma vineyards development in Tanzania. Regional Workshop held on June 16- 17, 2012, Dar-es-salaam, Tanzania.

[26] Mkenda, A.F., Luvanda, E.G., Rutasitara, L and Naho, A. 2004. Poverty in Tanzania. Comparisons across administrative regions.
[27] Msaki, M.M., Mwenda, M.I and Regnald, I.J. 2013. Cereal bank as a necessary rural livelihood institute in Arid land, Makoje Village, Dodoma village, Dodoma - Tanzania. Asian Economic and Financial Review, 3(2), 259-269.

[28] Mukhebi, A., Mbogoh, S and Matungulu, K. 2012. Climate change, agriculture and food security in Tanzania. Review of Development Economics, 16(3), 378-393

[29] Odoemenen, I. U and Obinne, C.P.O. 2010. Assessing the factors influencing the utilization of improved cereal crop production technologies by small-scale farmers in Nigeria. Indian Journal of Science and Technology. 3(1), 180-183.

[30] Omidvar, N., Ghazi-Tabatabie, M., Sadeghi, R., Mohammadi, $\mathrm{F}$ and Abbasi-Shavazi, M.J. 2013. Food insecurity and its socio demographic correlates among Afghsn Immigrants in Iran. Journal of Health Population and Nutrition, 3, 356- 366.

[31] Rakodi, C. 2002. A livelihoods approach: conceptual issues and definitions. Urban livelihoods: A people-centred approach to reducing poverty, 3-22.

[32] Sahn, D. E and Stifel, D. 2003. Exploring alternative measures of welfare in the absence of expenditure data. Review of income and wealth, 49(4), 463-489.

[33] Saka, J.O., Okoruwa, V.O., Lawal, B. O and Ajijola, S. 2005. Adoption of Improved Rice Varieties among Small-Holder Farmers in South-Western Nigeria. World Journal of Agricultural Sciences 1 (1), 42-49.

[34] Schmied, D. 1993. Managing food shortages in Central Tanzania. GeoJournal, 30(2), 153-158.

[35] Shiferaw, B., Obare, G and Muricho, G. 2006. Rural institutions and producer organizations in imperfect markets: Experiences from producer marketing groups in semi-arid eastern Kenya. Journal of SAT Agricultural Research, 2(1), $1-41$.

[36] Singh, S. 2013. Governance and upgrading in export grape global production networks in India: BWPI, The University of Manchester.

[37] Steduto, P., Hsiao, T. C., Raes, D and Fereres, E. 2012. Crop yield response to water: Food and Agriculture Organization of the United Nations.

[38] Stringer, L. C., Dyer, J. C., Reed, M. S., Dougill, A. J., Twyman, C and Mkwambisi, D. 2009. Adaptations to climate change, drought and desertification: local insights to enhance policy in southern Africa. Environmental Science and Policy, 12(7), $748-765$

[39] Swai, O. W., Mbwambo, J. S and Magayane, F. T. 2012. Gender and perception on climate change in Bahi and Kondoa Districts, Dodoma Region, Tanzania. Journal of African Studies and Development, 4(9), 218-231.

[40] Toledo, Á and Burlingame, B. 2006. Biodiversity and nutrition: A common path toward global food security and sustainable development. Journal of Food Composition and Analysis, 19(6), 477-483.

[41] United Republic of Tanzania. 2007. National Adaptation Programme of Action (NAPA), Vice President's Office, Division of Environment, p. 52.

[42] United Republic of Tanzania. 2013. Population and Housing Census. National Bureau of Statistics (Tanzania). 
[43] Weinberger, K and Lumpkin, T.A. 2007. 'Diversification into horticulture and poverty reduction: A research agenda'. World Development 35(8), 1464-1480 